\title{
Influence of Physico - Chemical Characteristics and Microbial Profile on Sensory Acceptability and Shelf Stability of Restructured Turkey Meat Nuggets in Refrigerated Storage
}

\author{
M. Anna Anandh* and R. Annal Villi
}

Department of Livestock Products Technology, Tamil Nadu Veterinary and Animal Sciences University, Veterinary College and Research Institute, Orathanadu-614 625, Thanjavur District, Tamil Nadu, India

*Corresponding author

\begin{tabular}{|c|c|}
\hline & A B S T R A C T \\
\hline $\begin{array}{l}\text { K e y w o r d s } \\
\text { Turkey, Meat, } \\
\text { Restructuring, } \\
\text { Nuggets, Quality, } \\
\text { Microbial profile, } \\
\text { Storage stability } \\
\end{array}$ & $\begin{array}{l}\text { Restructured turkey meat nuggets pr } \\
\text { to assess the quality changes at } 0,7, \\
\text { and tyrosine values were increased a } \\
(\mathrm{P}<0.01) \text { with increasing storage pe } \\
\text { moisture content. The results indicat } \\
\text { count, yeast and mould count and } \\
1.12 \pm 0.10 \text { to } 4.78 \pm 0.10,1.14 \pm 0\end{array}$ \\
\hline Article Info & 0.10 to $3.40 \pm 0.12$ and $1.10 \pm 0.12$ \\
\hline $\begin{array}{l}\text { Accepted: } \\
\text { 10 February } 2018 \\
\text { Available Online: } \\
10 \text { March } 2018 \\
\end{array}$ & $\begin{array}{l}\text { adverse effects were noticed on sen } \\
\text { and overall acceptability up to } 30 \\
\text { nuggets can be prepared and could } \\
\text { pouches under aerobic packaging. }\end{array}$ \\
\hline \multicolumn{2}{|l|}{ Introduction } \\
\hline \multicolumn{2}{|c|}{$\begin{array}{l}\text { Commercial turkey (Meleagris gallopavo) } \\
\text { farming is becoming popular in India and } \\
\text { farmers started to show interest in rearing } \\
\text { turkey birds. Recently, the consumption of } \\
\text { turkey meat is increasing worldwide and a } \\
\text { similar trend is also emerging in India. Turkey } \\
\text { meat has tremendous commercial viability } \\
\text { because of its low fat and cholesterol content } \\
\text { in comparison to red meat and other poultry } \\
\text { meat (Anna Anandh, et al., } 2012 \text { and Anna } \\
\text { Anandh, 2017). Popularization of turkey meat }\end{array}$} \\
\hline
\end{tabular}

and meat products through efficient technology is necessary to upgrade this back yard activity to a commercial business. Heavier size of turkey carcass make its effective utilization in value added meat product manufacture is a difficult task. Meat from turkey can be used profitably in the development of various value added meat products. Value addition of turkey meat improves preservation by inhibiting or deterring microbial decomposition /spoilage and results in flavorful and nutritious products. Restructuring technology can be 
used to produce value added products from low quality raw materials of meat industry, which are good sources of protein but are often underutilized. Restructured meat using flaking and forming or chunking and forming to produce low cost steaks has provided new steak products to consuming public (Mandigo, 1986). Products that undergone desinewing and particle size reduction such as sectioning, chunking, slicing, blade tenderization, flaking, chopping followed by forming into steaks, roasts or patties are called restructured meats (Hedrick et al., 1984). Value enhancement of raw materials, portion control, uniform quality and consumer convenience are advantages of restructured meat products. The objective of the present study was to prepare and evaluate the quality and acceptability of restructured turkey meat nuggets in refrigerated storage (4 $\left.\pm 1^{\circ} \mathrm{C}\right)$.

\section{Materials and Methods}

\section{Turkey meat}

Beltsville small white turkey (Meleagris gallopavo) were procured from instructional livestock farm complex and individually weighed after overnight fasting (except for water) and then slaughtered. The turkeys were killed by cutting the jugular vein and carotid artery on one side of the neck near atlanto occipital joint. After bleeding the carcasses were scalded at $58 \pm 2^{\circ} \mathrm{C}$ for $2 \mathrm{~min}$, handpicked and manually eviscerated. The meat separated from the turkey carcass and meat cut into small cubes. The turkey meat cubes were used for preparation of turkey meat nuggets.

\section{Product processing}

The formula for turkey meat nuggets were developed after conducting a series of preliminary trails. The product formulation consisted of $100 \%$ minced turkey meat, $2.5 \%$ salt, $2.5 \%$ cane sugar, $0.5 \%$ sodium tri polyphosphate, $0.015 \%$ sodium nitrite, 0.15 $\%$ sodium ascorbate, $2.0 \%$ spice mix, $6.0 \%$ condiments mix (onion, garlic and ginger 2:1:1) and $10 \%$ ice flakes. Weighed quantity of minced turkey meat samples were mixed in meat mixer at a speed of $200 \mathrm{rpm}$ for $2 \mathrm{~min}$ with salt $(2.7 \%)$, sodium tri polyphosphate $(0.5 \%)$ and minced buffalo meat (25\%). Thereafter, sodium nitrite $(0.015 \%)$, sodium ascorbate $(0.15 \%)$, spice mix $(2.0 \%)$ condiments mix $(6.0 \%)$ and ice flakes $(10 \%)$ were added to mixer and mixing was further continued for $3 \mathrm{~min}$ so as to obtain the homogenous mixture. Then about $500 \mathrm{gm}$ of meat mix was placed into rectangular aluminum mould and were packed compactly and covered. The moulds were then clipped and tied and the meat blocks were cooked in a pressure cooker without pressure for $30 \mathrm{~min}$ to reach the internal temperature of the cooked meat blocks to $80 \pm 2^{\circ} \mathrm{C}$. The internal temperature was recorded using digital probe thermometer. The cooked turkey meat blocks were cooled to room temperature, chilled overnight at $4 \pm 2^{\circ} \mathrm{C}$ and cut into $4 \mathrm{~cm} \times 1.5 \times$ $1.5 \mathrm{~cm}$ pieces using a meat slicer and packaged aerobically in LDPE pouches using a packaging machine (Roschermatic, Germany). The samples were kept at $4 \pm 1^{\circ} \mathrm{C}$ and examined at intervals of 7 days up to 30 days.

\section{Physico - chemical analysis}

The $\mathrm{pH}$ was determined using a digital $\mathrm{pH}$ meter (Century Instruments Ltd., India). Moisture content of the product was determined as per the procedure of AOAC (AOAC, 1995). For determination of extract release volume (ERV), $15 \mathrm{~g}$ of mined stored sample was blended with $60 \mathrm{ml}$ of distilled water in a homogenizer and homogenate was transferred as quickly as possible in to a funnel, equipped with a What man filter paper no.1. The volume of filtrate collected in first 
15 min was recorded as ERV of the respective sample. The procedure of Witte, et al., (1970) was followed to estimate thiobarbituric acid value (TBA). Tri-chloroacetic acid extracts of each sample was used for measuring the absorbance at $532 \mathrm{~nm}$. TBA value was calculated as $\mathrm{mg}$ malonaldehyde / $\mathrm{kg}$ meat sample by referring to a standard graph prepared using known concentration of malonaldehyde. Thyrosine value of stored samples was determined based on the procedure of Strange, et al., (1977).

\section{Microbial analysis}

Total plate, psychrotrophic, coliform, yeast and mold and staphylococcal counts of stored samples were determined by the methods described by APHA (1984). Readymade media (Hi-media Laboratory Pvt. Ltd., Mumbai, India) was used for microbial count. Preparation of samples and serial dilutions were done near the flame in a horizontal laminar flow cabinet which was pre sterilized by ultraviolet irradiation (Yarco Sales Pvt. Ltd., Mumbai, India) observing all possible aseptic precautions. Tenfold dilution of each samples were prepared aseptically by blending $10 \mathrm{~g}$ of sample with $90 \mathrm{ml}$ of $0.1 \%$ sterile peptone water with a pre sterilized blender. Plating medium was prepared and autoclaved at $15 \mathrm{lb}$ pressure for $15 \mathrm{~min}$ before plating. The plates were incubated at $30 \pm 1^{\circ} \mathrm{C}$ for $48 \mathrm{~h}$ for total plate count (TPC) and $4 \pm 1^{\circ} \mathrm{C}$ for 14 days for psychrotrophic counts. Coliform count was done using double layer violet red bile agar and plates were incubated at $37 \pm$ $1^{\circ} \mathrm{C}$ for $48 \mathrm{~h}$. Acidified potato dextrose agar ( $\mathrm{pH}$ 3.5) was used for enumeration of yeast and mold with incubation at $25 \pm 1{ }^{\circ} \mathrm{C}$ for 5 days. Baird Parker Agar was used for staphylococcal count. Before plating, the medium was heated to $50{ }^{\circ} \mathrm{C}$ and egg yolk tellurite emulsion was added to the medium. The plates were incubated at $37 \pm 1{ }^{\circ} \mathrm{C}$ for $48 \mathrm{~h}$ and the plates showing $30-300$ colonies were counted. The average number of colonies for each species was expressed as $\log 10 \mathrm{cfu} / \mathrm{g}$ sample.

\section{Sensory evaluation}

Restructured turkey meat nuggets were served to an experienced panel of scientists and students in the discipline of Livestock Products Technology to determine their sensory characteristics. The sensory attributes like appearance and colour, flavour, juiciness, texture and overall acceptability were evaluated on 8 point descriptive scale as suggested by Keeton (1983). The sensory score of 8 was extremely desirable, where as one was extremely undesirable.

\section{Statistical analysis}

The data generated from four trials were analyzed by following standard procedures of Snedecor and Cochran (1989) for comparing the means and to determine the effect of storage.

\section{Results and Discussion}

\section{Changes in physico - chemical characteristics}

The mean values for physico - chemical characteristics of restructured turkey meat nuggets during refrigerated storage are presented in Table 1 . The overall days means of $\mathrm{pH}$ ranged between $6.68 \pm 0.04$ to $6.01 \pm 0.02$. Restructured turkey meat nuggets $\mathrm{pH}$ decreased significantly $(\mathrm{P}<0.01)$ with increasing storage period. However, no significant variation in $\mathrm{pH}$ up to 7 days of refrigerated storage, but it significantly decreased on day 14 of storage. A further significant $(\mathrm{P}<0.01)$ decrease in $\mathrm{pH}$ was observed on day 21 of storage and the value did not different from day 30 of storage. Significant decrease in $\mathrm{pH}$ of restructured pork 
rolls during refrigerated storage also reported Devatkal and Mendiratta (2001). Increased pH of turkey meat nuggets during refrigerated storage might be due to hydrolysis of the collagen molecules which released amino group in meat system (Webster, et al., 1982). The overall days means of moisture content ranged between $69.10 \pm 0.14$ to $68.52 \pm 0.10$ $\%$. Gradual decrease in moisture content was recorded during storage. However, the decrease was non - significant. These variations in moisture content during storage might be due to some dehydration from permeable film during refrigerated storage. Overall days means of ERV ranged from $22.24 \pm 0.18$ to $20.16 \pm 0.10 \mathrm{ml}$. During storage, non-significant decrease in ERV value was observed up to 14 days of storage. However, significant $(\mathrm{P}<0.01)$ decrease in ERV value was observed on day 21 of storage and the value did not different from day 30 of storage. This might be due to gradual increase in microbial growth during storage (Jay, 1996). Overall days means of TBA ranged between $0.58 \pm 0.14$ to $0.91 \pm 0.12 \mathrm{mg}$ malonaldehyde / $\mathrm{kg}$ meat. The TBA values non significantly increased with increasing storage period up to day 7 of storage and significantly $(\mathrm{P}<0.01)$ increased after on day 14 of storage. Increased TBA value between days 21 to 30 of refrigerated storage did not differ significantly between them. Even though there was a increase in TBA values during storage, they were well within the threshold limit of 1-2 mg malonaldehyde / kg meat (Wastt, 1962). Increase in TBA values might be due to increase in lipid oxidation and production of volatile metabolites in aerobic packaging. Increase in TBA during storage of different meat and meat products were also recorded earlier by Tarladgis, et al., (1960) and Devatkal and Mendiratta (2001). Overall days mean of tyrosine ranged between $0.32 \pm$ 0.10 to $0.69 \pm 0.10 \mathrm{mg}$ tyrosine / $100 \mathrm{~g}$. Tyrosine value increased significantly $(\mathrm{P}<0.01)$ with increasing storage period.
However, increase in tyrosine value between 14 to 21 days did not turn out to statistically significant. The increase in tyrosine during storage might be due to denaturation and subsequent proteolysis (Daly, et al., 1976).

\section{Changes in microbial quality}

The mean values for microbial profile of restructured turkey meat nuggets during refrigerated storage are presented in Table 2. Overall days mean for total plate count increased progressively and significantly $(\mathrm{P}<0.01)$ with increasing storage period and it ranged from $1.12 \pm 0.10$ to $4.78 \pm 0.10 \log _{10}$ cfu / g. However, from day 21 to 30 of storage, the increase in total plate counts were non-significant. Similar results of increasing total plate counts with increasing storage period were also reported by Devatkal and Mendiratta (2001) in restructured pork rolls. Overall days means for psychrophilic count ranged between $1.14 \pm 0.12$ to $4.52 \pm 0.10$ $\log _{10}$ cfu / g. Significant $(\mathrm{P}<0.01)$ increase in psychrotrophic count was observed with increasing storage period. A consistent increase in psychrotrophic counts on all storage days in ground chevon during refrigerated storage was also reported Verma and Sahoo (2000). Overall days means for coliform counts increased significantly $(\mathrm{P}<0.01)$ with increasing storage period from $1.10 \pm 0.12 \log _{10} \mathrm{cfu} / \mathrm{g}$ on day 7 of storage to $2.92 \pm 0.12 \mathrm{log}$ cfu / g on day 30 of storage period. The coliform counts were increased significantly $(\mathrm{P}<0.01)$ with increasing storage period. However, between day 7 to 14 and day 21 to 30 of storage, the increase in coliform counts were non-significant. Overall days mean for yeast and mold count ranged from $1.18 \pm 0.10$ to $3.40 \pm 0.12 \log _{10} \mathrm{cfu} / \mathrm{g}$. The yeast and mould counts also increased significantly $(\mathrm{P}<0.01)$ with increasing storage period. However, between day 0 to 7 and day 14 to 21 of storage, the increase in yeast and mould counts were non-significant. 
Table.1 Changes in physico-chemical characteristics of restructured turkey meat nuggets during refrigerator storage $\left(4 \pm 1^{\circ} \mathrm{C}\right)$

\begin{tabular}{|c|c|c|c|c|c|}
\hline \multirow[t]{2}{*}{ Parameters } & \multicolumn{5}{|c|}{ Storage period in days } \\
\hline & $\mathbf{0}$ & 7 & 14 & 21 & 30 \\
\hline \multicolumn{6}{|l|}{ Physico-chemical characteristics* } \\
\hline $\mathrm{pH}$ & $6.68 \pm 0.04^{\mathrm{a}}$ & $6.62 \pm 0.02^{\mathrm{a}}$ & $6.04 \pm 0.04^{b}$ & $6.02 \pm 0.02^{b}$ & $6.01 \pm 0.02^{b}$ \\
\hline Moisture (\%) & $69.10 \pm 0.14$ & $68.98 \pm 0.10$ & $68.80 \pm 0.08$ & $68.68 \pm 0.12$ & $68.52 \pm 0.10$ \\
\hline Extract release volume (ml) & $22.24 \pm 0.18^{\mathrm{a}}$ & $22.21 \pm 0.14^{\mathrm{a}}$ & $22.15 \pm 0.12^{\mathrm{a}}$ & $20.10 \pm 0.14^{b}$ & $20.16 \pm 0.10^{b}$ \\
\hline TBA value (mg malonaldehyde / kg meat) & $0.58 \pm 0.14^{\mathrm{a}}$ & $0.62 \pm 0.10^{\mathrm{a}}$ & $0.71 \pm 0.12^{b}$ & $0.87 \pm 0.14^{\mathrm{c}}$ & $0.91 \pm 0.12^{c}$ \\
\hline Thyrosine value (mg tyrosine/100g) & $0.32 \pm 0.10^{\mathrm{a}}$ & $0.48 \pm 0.12^{b}$ & $0.53 \pm 0.10^{c}$ & $0.55 \pm 0.12^{c}$ & $0.69 \pm 0.10^{d}$ \\
\hline
\end{tabular}

$*$ Number of observations $=4$. Means bearing same superscripts row - wise do not differ significantly.

Table. 2 Changes in microbial profile of restructured turkey meat nuggets during refrigerator storage $\left(4 \pm 1^{\circ} \mathrm{C}\right)$

\begin{tabular}{|c|c|c|c|c|c|}
\hline \multirow[t]{2}{*}{ Parameters } & \multicolumn{5}{|c|}{ Storage period in days } \\
\hline & $\mathbf{0}$ & 7 & 14 & 21 & 30 \\
\hline \multicolumn{6}{|c|}{ Microbial profile $(\log 10 \mathrm{cfu} / \mathrm{gm}) * *$} \\
\hline Total plate count & $1.12 \pm 0.10^{\mathrm{a}}$ & $1.52 \pm 0.10^{\mathrm{b}}$ & $3.52 \pm 0.10^{c}$ & $4.42 \pm 0.12^{\mathrm{d}}$ & $4.78 \pm 0.10^{\mathrm{d}}$ \\
\hline Psychrotrophic count & ND & $1.14 \pm 0.16^{\mathrm{a}}$ & $2.58 \pm 0.10^{b}$ & $3.44 \pm 0.10^{c}$ & $4.52 \pm .10^{d}$ \\
\hline Coliform count & ND & $1.10 \pm 0.12^{\mathrm{a}}$ & $1.14 \pm 0.12^{\mathrm{a}}$ & $2.90 \pm 0.10^{b}$ & $2.92 \pm 0.11^{c}$ \\
\hline Yeast and mould count & $1.18 \pm 0.10^{\mathrm{a}}$ & $1.21 \pm 0.12^{\mathrm{a}}$ & $2.33 \pm 0.10^{b}$ & $2.37 \pm 0.12^{b}$ & $3.40 \pm 0.12^{c}$ \\
\hline Staphylococcal count & $1.10 \pm 0.12^{a}$ & $1.22 \pm 0.14^{\mathrm{a}}$ & $2.48 \pm 0.10^{b}$ & $2.52 \pm 0.14^{b}$ & $3.98 \pm 0.14^{\mathrm{c}}$ \\
\hline
\end{tabular}

$* *$ Number of observations $=4$. Means bearing same superscripts row - wise do not differ significantly.

Table.3 Changes in sensory characteristics of restructured turkey meat nuggets during refrigerator storage $\left(4 \pm 1^{\circ} \mathrm{C}\right)$

\begin{tabular}{|c|c|c|c|c|c|}
\hline \multirow[t]{2}{*}{ Parameters } & \multicolumn{5}{|c|}{ Storage period in days } \\
\hline & $\mathbf{0}$ & 7 & 14 & 21 & 30 \\
\hline \multicolumn{6}{|l|}{ Sensory attributes***** } \\
\hline Appearance and colour & $7.5 \pm 0.02^{\mathrm{a}}$ & $7.4 \pm 0.02^{\mathrm{a}}$ & $7.3 \pm 0.04^{\mathrm{a}}$ & $6.7 \pm \pm 0.02^{b}$ & $5.8 \pm 0.02^{c}$ \\
\hline Flavour & $7.4 \pm 0.04^{\mathrm{a}}$ & $7.2 \pm 0.02^{\mathrm{a}}$ & $6.3 \pm 0.04^{b}$ & $6.2 \pm 0.02^{b}$ & $5.4 \pm 0.02^{\mathrm{c}}$ \\
\hline Juiciness & $7.2 \pm 0.02^{\mathrm{a}}$ & $7.1 \pm 0.02^{\mathrm{a}}$ & $7.0 \pm 0.04^{\mathrm{a}}$ & $6.1 \pm 0.02^{\mathrm{b}}$ & $5.2 \pm 0.02^{\mathrm{c}}$ \\
\hline Texture & $7.0 \pm 0.14^{\mathrm{a}}$ & $6.4 \pm 0.04^{b}$ & $6.3 \pm 0.02^{\mathrm{b}}$ & $6.2 \pm 0.04^{b}$ & $5.4 \pm 0.04^{c}$ \\
\hline Over all acceptability & $7.1 \pm 0.06^{\mathrm{a}}$ & $6.9 \pm 0.10^{\mathrm{a}}$ & $6.5 \pm \pm 0.08^{b}$ & $6.4 \pm 0.10^{b}$ & $5.9 \pm 0.04^{c}$ \\
\hline
\end{tabular}

$* * *$ Number of observations $=20$. Means bearing same superscripts row - wise do not differ significantly.

$* * *$ Sensory attributes of restructured turkey meat nuggets were evaluated on a 8 - point descriptive scale (wherein $1=$ extremely undesirable; $8=$ extremely desirable). 
Overall days means for staphylococcal counts significantly $\quad(\mathrm{P}<0.01) \quad$ increased with increasing storage period and it was $1.10 \pm$ $0.12 \log _{10} \mathrm{cfu} / \mathrm{g}$ on 0 day and increased to $3.98 \pm 0.14 \log _{10} \mathrm{cfu} / \mathrm{g}$ on day 30 of storage. Non-significant increases in staphylococcal counts were also observed between day 0 to 7 and 14 to 21 of storage. Afterwards there was a significant increase in staphylococcal counts. Throughout the storage period, all microbial counts were within the standards stipulated for cooked meat products, even though microbial counts were increased with increasing storage period (Jay, 1996). No visible slim and off odour appeared up to day 21 of storage in restructured turkey meat nuggets. However, on day 30 of storage, the stored product revealed marginally spoiled stage with appearance of surface slim and slight off odour.

\section{Changes in sensory attributes}

The mean values for sensory attributes of restructured turkey meat nuggets during refrigerated storage are presented in Table 3. Overall days means for appearance and colour ranged from $7.5 \pm 0.02$ to $5.8 \pm 0.02$. No significant difference was observed for appearance and colour scores up to day 14 of storage. However, appearance and colour scores decreased significantly $(\mathrm{P}<0.01)$ after day 21 of storage. The possible reason for decrease in appearance and colour scores during refrigerated storage might be due to surface drying or lipid oxidation causing non - enzymatic browning. Flavour scores decreased with increasing storage period and ranged from $7.4 \pm 0.04$ to $5.4 \pm 0.02$. However, between day 0 to 7 and day 14 to 21 of storage, the decrease in flavour scores were non-significant. Flavour scores significantly decreased on day 30 of storage. Flavour reduction during storage might be due to microbial growth and lipid oxidation (Tarladgis, et al., 1960). Overall days means for juiciness scores decreased significantly $(\mathrm{P}<0.01)$ with increasing storage period and ranged from $7.2 \pm 0.02$ to $5.2 \pm 0.02$, but the decline was non-significant up to on day 14 of storage after that decreased significantly $(\mathrm{P}<0.01)$ on day 21 of storage. Dehydration and moisture reduction of the product with advancement of refrigerated storage could be the reason for lower juiciness scores. Overall days means for texture scores decreased with increasing storage period and it ranged from $6.7 \pm 0.08$ to $6.5 \pm 0.10$. The texture scores decreased significantly $(\mathrm{P}<0.01)$ with increasing storage period and there was in non-significant decrease in texture scores were observed between on day 7 to 21 of storage. Overall acceptability scores ranged from $7.1 \pm 0.06$ to $5.9 \pm 0.04$. Overall acceptability scores decreased with increasing storage period. However, there was no significant difference in overall acceptability of the products up to day 7 of storage. A significant $(\mathrm{P}<0.01)$ decrease in overall acceptability scores was observed only on day 14 of storage. Reduction in overall acceptability scores between days 14 to 21 did not significantly between them but it significantly decreased on day 30 of storage. Decrease in overall acceptability scores with increasing storage period might be due to decrease in appearance and colour, flavour, juiciness and texture scores. Similar observation of decrease in overall acceptability with increasing storage period was also reported by Devatkal and Mendiratta (2001) in pork rolls.

Based on the above results, it can be concluded that restructured turkey meat nuggets had better acceptability up to 21 days of storage at $4 \pm 1^{\circ} \mathrm{C}$ in LDPE pouches.

\section{References}

Anna Anandh, M. 2017. Effect of rearing systems on slaughter and carcass 
characteristics of turkey (Meleagris gallopavo). Research Journal of Animal Husbandry and Dairy Science, 8:46-50.

Anna Anandh, M., Richard Jagatheesan, P.N., Senthil Kumar, P., Paramasivam, A. and Rajarajan, G. 2012. Effect of rearing systems on reproductive performance of turkey. Veterinary World, 5:226-229.

AOAC, Association of Official Analytical Chemists. 1995. Official methods of Analysis (16 ${ }^{\text {th }}$ ed.). Washington, DC.

APHA, American Public Health Association (1984). In M. L. Speck (Ed.),

Compendium of methods for the microbiological examination of foods (2nd ed.).Washington, DC.

Daly, M.C., Morrisey, P.A. and Buckley D.J. 1976. Quality of raw minced beef. Irish Journal of Agriculture Research, 15:283.

Devatkal, S. and Mendiratta, S.K. 2001. Use of calcium lactate with salt phosphate and alginate calcium gel in restructured pork rolls. Meat Science, 58:371-379.

Hedrick, H.B., Aberie, E.T., Forrest, J.C., Judge, M.D. and Merkel, R.A. 1994. Principles of Meat Science. $3^{\text {rd }}$ edn. Kendell/Hunt Publishing Co., Iowa.

Jay, J.M. 1996. Modern Food Microbiology. $4^{\text {th }}$ edn. CBS Publishers and Distributors, Delhi. India.

Keeton, J.T., 1983. Effect of fat and Nacl / Phosphate levels on the chemical and sensory properties of pork patties. Journal of Food Science, 48: 878 - 881.
Mandigo, R.W. 1986. Restructuring of muscle foods. Food Technology. 40:85-89.

Snedecor, G.W. and Cochran, W.G. 1989. Statistical Methods, $8^{\text {th }}$ edn. Oxford and IBH Publishing Co., Calcutta.

Strange, E.D., Benedict, R.C., Smith, J.L. and Swift, G.E. 1977. Evaluation of rapid tests for monitoring alterations in meat quality during storage. I. Intact meat. Journal of Food Protection, 40:843847.

Tarladgis, B.G., Watts, B.M., Younathan, M.T and Dugan, L. R. 1960. A distillation method for the quantitiative determination of malonaldehyde in rancid foods. Journal of American Oil Chemists Society, 37: 403-406.

Verma, S. P. and Sahoo, J. (2000). Synergistic effect of L-ascorbic acid and alphatocopherol acetate on quality of ground chevon during refrigerated storage. Journal of Food Scence and Technology, 38: 220-226.

Wastt, B.M., 1962. Meat products. In: Symposium on food lipids and their oxidation. AVI publishing co. Inc., Westport CT.

Webster, J.D., Ledward, D.A. and Lawrie, R.A. 1982. Protein hydrolysates from meat industry byproducts. Mat Science, 7:147-157.

Witte, V.C., Krauze, G.F. and Bailey, M.E. 1970. A new extraction method for determining 2-thiobarbituric acid values of pork and beef during storage. Journal Food Science, 35:582-585.

\section{How to cite this article:}

Anna Anandh, M. and Annal Villi, R. 2018. Influence of Physico - Chemical Characteristics and Microbial Profile on Sensory Acceptability and Shelf Stability of Restructured Turkey Meat Nuggets in Refrigerated Storage. Int.J.Curr.Microbiol.App.Sci. 7(03): 1263-1269. doi: https://doi.org/10.20546/ijcmas.2018.703.149 